森林表土播きだしによる荒廃地緑化に関する研究

\author{
陣門泰輔・佐藤治雄・森本幸裕
}

大阪府立大学農学都

\title{
A Preliminary Study of Revegetation of Disturbed Area from Forest Seedbanks
}

\author{
Jimmon, Taisuke, SATO, Haruo and Morimoto, Yukihiro \\ Fac. of Agri., Osaka Pref. Univ.
}

\begin{abstract}
要旨：本研究では森林表土の持つポテンシャルを評価し，その利用法を検討することを目的とした。 大阪府茨木市のアベマキ林, モウソウチク林, 千早赤阪村のシイ林, 泉佐野市のコナラーアオモジ林, 兵庫県西宮市のアカマツ林の森林表土を荒廃地のモデルとした土壌基盤に播きだし, 活性炭素混入, 施 肥, 土壌基盤・マ少土との混合，コバノミツバッツジの追加播種などの追加処理を行い，全木本発芽個 体の消長, 高さ・葉張りを追跡調査した。どの森林表土からもアカメガシワなどの先駆木本種の発芽が みられ，成長を続けた。森林表土播きだしが荒廃地における早期の植生回復に有効であり，施肥によっ てより早期の植生回復が望めることがわかった。
\end{abstract}

キーワード：埋土種子, 植生回復, ポテンシャル

Key words : Seedbank, Revegetation, Potential

1.はじめに

近年，荒廃地緑化の一手段として，森林表土を播 きだし，表土中に存在する埋土種子を利用した植生 回復が試みられるようになってきた。例えば，大阪 府箕面ダム建設の際に生じた裸地面の緑化に，水没 予定地の森林表土の播きだしを実地に行った梅原・ 永野1) の研究 (1980) , 山火事跡地においてアカマ ツ林の表土播きだしを行った中越ら ${ }^{2)}$ （1977）の研 究, 越水ら ${ }^{3)}$ (1997) による土袞シードバンクを用 いた湿性植物の復元など埋土種子からの自然性, 郷 土性を重視した植生回復を期待した基礎研究や実地 施工例などが蓄積されつつある。

これらの研究からは, 森林表土の播きだしにより， 自然遷移に任せるより短い時間で先駆低木林の段階
に回復できることが明らかとなってきた。しかし， どこの森林表土も, 同程度の植生回復ポテンシャル を持つかは必ずしも明らかでなく，そのポテンシャ ルを最大限に引き出すための処理や管理方法の開発 も必要であり, 森林表土播きだしによる植生回復工 法に関しては，実証的研究によって解明すべき点が 多く残されている。

本論文では基礎研究として, ていねいな管理や処理 のもとで森林表土の持つ植生回復ポテンシャルを検 討するための数種森林表土の植生回復ポテンシャル 検討試験と，実用化を視野に入れた粗放な管理のも とでの森林表土播きだし工法実用化検討試験のふた つの実験を行い, 表土中に存在する埋土種子の発芽, 成長の追跡調査から, 森林表土の持つ様々なポテン シャルを評価し，その利用法を研究することとした。 


\section{2. 実験方法}

2. 1. 数種森林表土の植生回復ポテンシャル検討試験 1997年6月7日，大阪府茨木市国際文化公園都市造 成地内のアベマキ林 $\mathrm{A}$ (尾根) $\mathrm{B}$ (山腹) およびモウソ ウチク林, 大阪府南河内郡千早赤阪村建水分神社の シイ林傾斜地の上部と下部，兵庫県西宮市ゴロゴロ 岳山頂付近のアカマツ林Aおよび奥池付近のアカマ ツ林Bにおいて, L層を除く $\mathrm{A}_{0}$ 層と $\mathrm{A}_{1}$ 層を埋土種子が含 まれている土壤と考え, それぞれ厚さ約 $5 \mathrm{~cm}$ 表土を 採取し, 大阪府枚方市山田池公園造成地内の灌水処 理を施した試験区 $(0.6 \mathrm{~m} \times 1 \mathrm{~m}$, 繰り返し2回)に $3 \mathrm{~cm} /$ 厚 で播きだした。なお，試験区を飛来種子防止のため の白色寒冷紗で覆った。また, 表土に粒状活性炭素 混入，コバノミツバツツジ追加播種，マサ土との等 量混合等の追加処理も行った。調査は 3 年間行い, 1 年目は1週間ごとに発芽・枯死数とその種名を記録, 4 週間ごとに草丈およひ葉張りを測定し， 2 年目以降 は4週間ごとに木本個体の消長と生存個体の高さ・葉 張りを測定した。

\section{2. 森林表土播きだし工法実用化検討試験}

1998年4月 17 日, 大阪府泉佐野市上之哪における林 道東山堀河線開設工事の際にコナラーアオモジ林の 森林表土約 $30 \mathrm{~cm}$ 厚をブルドーザーで集め, 堺第7-3 区に設けた実験区（大和川下流域の浚渫土砂 9 : コン ポスト 1 の混合土を $50 \mathrm{~cm}$ 厚に敷き詰めた) に厚さ $5 \mathrm{~cm}$ で播きだし，乾燥時に灌水を行った。また基本処理 区，粒状活性炭素10\%混入区，土袞基盤と表土との等 量混合区，これら 3 区にマグアンプ $\mathrm{K}(\mathrm{N}: \mathrm{P}: \mathrm{K}=6: 40: 6)$ を施肥した区，計6区（1区画は0. $8 \mathrm{~m} \times 4 \mathrm{~m}$ が3畧，基 (*i劰吸理中，会す

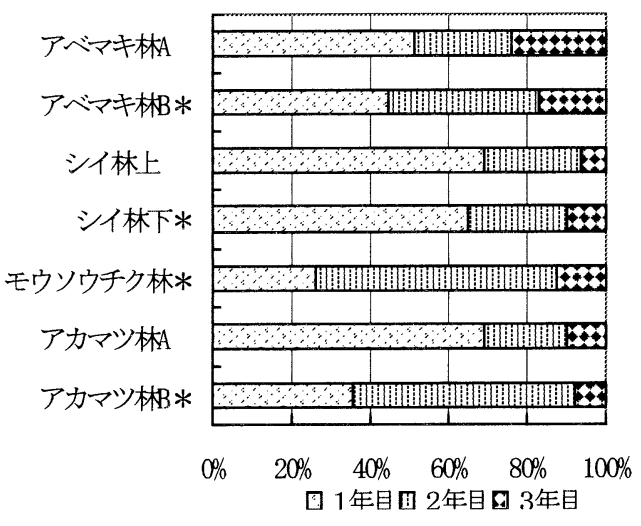

図 1 森林タイプ別 3 年間の発芽個体数の割合

本処理区と施肥区のみ繰り返し2回）を設けた。調査 は2年間行い，4週間ごとに発芽木本個体の高さ・葉 張りを測定し，草本種の種名と被度を記録した。

\section{3. 結果および考察}

3. 1. 数種森林表土の植生回復ポテンシャル検討試験 3.1.1. 発芽傾向

どの森林タイプからもヌルデ，アカメガシワなど 二次林の先駆木本種の発芽がみられた。常緑高木種 は個体数, 種数ともに少なかったが, シイ林ではツ ブラジイのような極相林構成種もみられた。表1によ ると，播きだし直後に発芽する種としてヌルデ，ア カメガシワ, 2 年目に初めて発芽する種としてソヨゴ, 3年目に初めて発芽する種としてエノキが挙げられ

\begin{tabular}{|c|c|c|c|c|c|}
\hline \multicolumn{3}{|c|}{ 表 1 各森林タイプにおける主要木本種の消長 } & & \multicolumn{2}{|c|}{ (*追加処理区も含む) } \\
\hline 森林タイプ & 播きだし直後に発芽した種 & $\begin{array}{l}2 \text { 年目に初めて発 } \\
\text { 芽した種 }\end{array}$ & $\begin{array}{l}3 \text { 年目に初めて } \\
\text { 発芽した種 } \\
\end{array}$ & $\begin{array}{l}\text { 2. 3年目にも発芽 } \\
\text { した種 }\end{array}$ & $\begin{array}{l}2.3 \text { 年目に枯死 } \\
\text { した種 }\end{array}$ \\
\hline アベマキ林A & $\begin{array}{l}\text { ヌルデ、アカメガシワ、ヤ } \\
\text { マハギ、タラノキなど10種 }\end{array}$ & $\begin{array}{l}\text { センダン、マン } \\
\text { リヨウなど3種 }\end{array}$ & なし & $\begin{array}{l}\text { ヌルデ、アカメ } \\
\text { ガシワなど6種 }\end{array}$ & $\begin{array}{c}\text { ヒサカキ、ヌル } \\
\text { デなど6種 }\end{array}$ \\
\hline アベマキ林B* & $\begin{array}{l}\text { マルデ、アカメガシワ、ヤ } \\
\text { マグワ、キリなど7種 }\end{array}$ & \begin{tabular}{|l} 
クロモジ、ツタ \\
の2種
\end{tabular} & $\begin{array}{l}\text { エノキ、ヤマザ } \\
\text { クラなど2種 } \\
\end{array}$ & $\begin{array}{l}\text { ヌルデ、ヤブュ } \\
\text { ウジなど10種 }\end{array}$ & $\begin{array}{c}\text { ヒサカキ、タラ } \\
\text { ノキなど5種 }\end{array}$ \\
\hline シイ林上部 & $\begin{array}{l}\text { マルデ、アカメガシワ、ヤ } \\
\text { マグワ、センダンなど9種 }\end{array}$ & なし & \begin{tabular}{|l} 
ヤマザクラの1 \\
種
\end{tabular} & $\begin{array}{l}\text { ヌルデ、アカメ } \\
\text { ガシワなど } 5 \text { 種 }\end{array}$ & $\begin{array}{c}\text { ヒサカキ、ヤマ } \\
\text { グワなど3種 }\end{array}$ \\
\hline シイ林下部* & $\begin{array}{l}\text { ヌルデ、アカメガシワ、ヤ } \\
\text { マグワ、キリなど11種 }\end{array}$ & ナンテンの1種 & \begin{tabular}{|l|} 
エノキ、クマノ \\
ミズキなど4種 \\
\end{tabular} & ヌルデなど7種 & $\begin{array}{l}\text { ヒサカキ、ツブ } \\
\text { ラジイなど11種 }\end{array}$ \\
\hline モウソウチク林* & $\begin{array}{l}\text { ヌルデ、アカメガシワ、セ } \\
\text { ンダン、クサギの4種 }\end{array}$ & $\begin{array}{l}\text { ソョゴ、ヤマサ } \\
\text { クラなど5種 } \\
\end{array}$ & ウツギなど2種 & $\begin{array}{c}\text { ヌルデ、ヒサカ } \\
\text { キなど5種 }\end{array}$ & $\begin{array}{c}\text { ヒサカキ、ヌル } \\
\text { デなど5種 }\end{array}$ \\
\hline アカマツ林A & $\begin{array}{l}\text { ヌルデ、アカメガシワ、タ } \\
\text { ラノキの3種 }\end{array}$ & ソヨゴなど2種 & \begin{tabular}{|l|} 
ハゼノキ、リョ \\
ウブなど3種 \\
\end{tabular} & $\begin{array}{c}\text { ヌルデ、ヒサカ } \\
\text { キの2種 }\end{array}$ & $\begin{array}{c}\text { ヒサカキなど2 } \\
\text { 種 } \\
\end{array}$ \\
\hline アカマツ林 $\mathrm{B}^{*}$ & $\begin{array}{l}\text { ヌルデ、アカメガシワ、イ } \\
\text { ヌザンショウの3 種 } \\
\end{array}$ & $\begin{array}{l}\text { ソョゴ、イソノ } \\
\text { キなど7種 } \\
\end{array}$ & $\begin{array}{l}\text { エノキ、ハゼノ } \\
\text { キなど4種 } \\
\end{array}$ & $\begin{array}{l}\text { ヌルデ、アカメ } \\
\text { ガシワなど8種 } \\
\end{array}$ & \begin{tabular}{|c|} 
ソョゴ、リョウ \\
ブなど7種
\end{tabular} \\
\hline
\end{tabular}




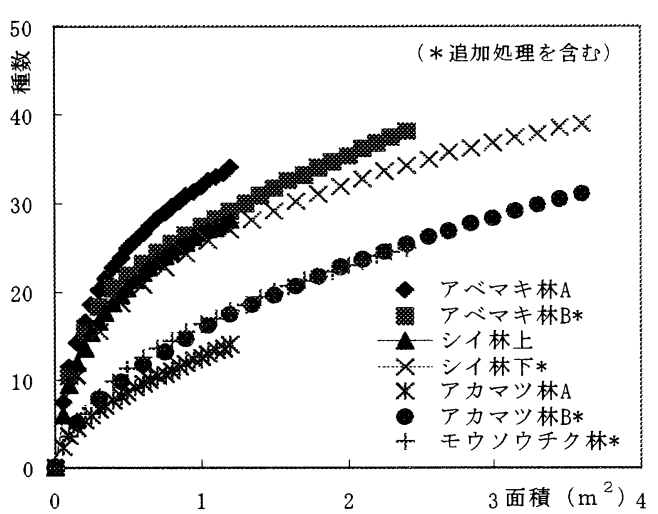

図 2 森林タイプ別の種数一面積曲線

た。3年間を通じ発芽のみられた種としてアカメガシ ワ，ヌルデが挙げられた。また，アカマツ林やモウ ソウチク林の表土において，ヒサカキやソヨゴの大 量発芽と枯死がみられた。森林タイプによっては, 発芽種に若干の違いがあり, 種によっては, 発芽時 期が異なることがわかった。

図1によると，各森林タイプにおいて 3 年間の全発 芽木本個体数のうち, 1 年目に発芽するのが $25 〜 70 \%$, 2 年目が $20 〜 60 \%, 3$ 年目が5〜 25\%であった。このよう に, 年が経るにつれ, 発芽個体数が減っているため, 2. 3年目の発芽がそれよりも前に発芽した植物の被 覆によって，抑制されていることが考えられる。ま た，「モウソウチク林」や「アカマツ林B」で 1 年目 よりも2年目以降の発芽数が多くなっていることか ら，表土播きだしによる植生回復においては長期的 視野で見守る必要があると考えられる。

図2は森林タイプ別に発芽した植物種の種数一面 積曲線を表したものである。全体的にみると，2つの 集団, 初期の増加速度の大きい「アベマキ林」「シ イ林」のグループと初期の増加速度の小さい「モウ ソウチク林」「アカマツ林」のグループに分けるこ とができる。この違いは, 表土中に存在する埋土種 子の密度の違いによるものだと考えられ，遷移の進 んだアカマツ林や植生の貧弱なモウソウチク林の森 林表土より極相期にはいったシイ林や植生豊かなア ベマキ林の森林表土の方が, 種多様性を高めるとい う点からみると, 植生回復ポテンシャルは高いと考 えられた。

\subsection{2. 木本発芽個体数の推移}

図3はアベマキ林B活性炭素混入区の木本発芽個体 数の推移を表したものである。1年目は播きだし1〜2 と 4 週間後, 2 年目は 7 月月に発芽数のピークをみる

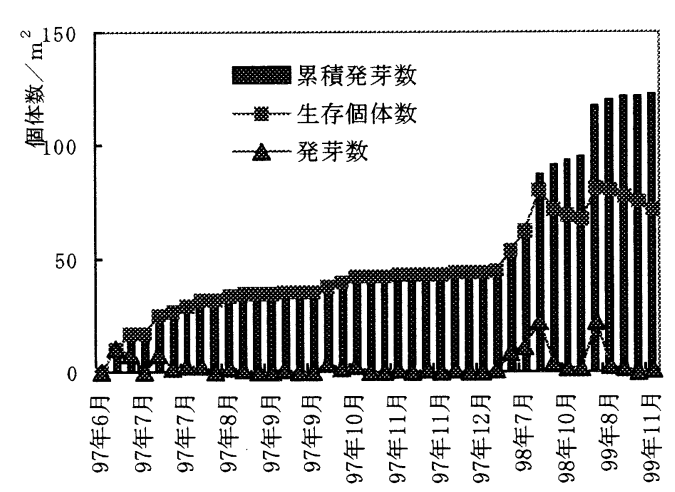

図3「アベマキ林B活性炭混入区」 における発芽個体数の推移

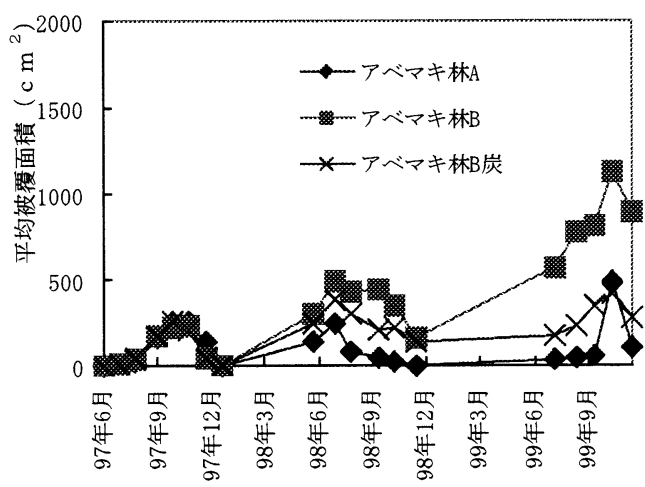

図4 アベマキ林における被覆面積の推移

ことができ, 2 年目から累積発芽数と生存個体数の差, すなわち枯死が目立つようになった。この傾向はど の森林タイプ, 追加処理区においてもみられた。こ のことから, 追加処理や森林タイプが違っても発芽 時期に与える影響は少なかったと言える。

\subsection{3. 初期成長}

図4はアベマキ林における3年間のアカメガシワの 成長推移を表したものである。1 年目の推移には処 理による大きな違いがみられなかったが, 2 年目以降 「アベマキ林B」や「シイ林下部」の方が高い值を示 すようになった。これは, 地形条件の違いが土壌中 に含まれる土壤微生物, 共生菌根菌, 栄養分などの 差違を生み, それが埋土種子の成長に影響した可能 性を示唆している。

\subsection{4.まとめ}

どの森林タイプからも表土中に存在する埋土種子 が発芽, 成長したので, どの森林タイプにおいても 植生回復ポテンシャルを持っていることが分かった。 また, 森林表土によって, ポテンシャルに多少の違 いがあり，その違いが現地植生や遷移状況, 地形条 件の違いによるものだと考えられた。 


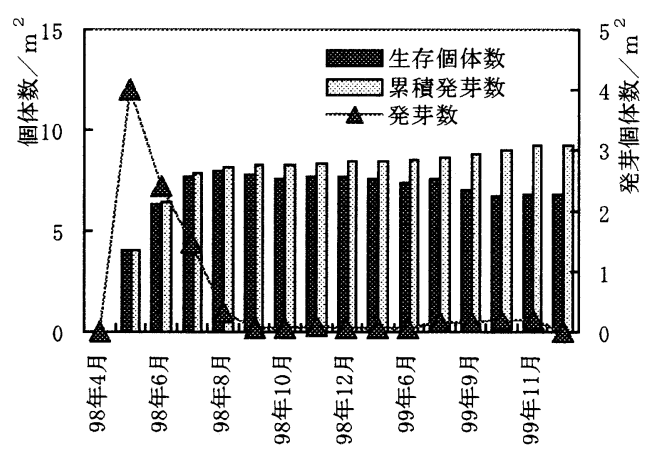

図 5 「施肥区」における木本発芽個体数の推移

\section{2. 森林表土播きだし工法実用化検討試験}

\subsection{1. 発芽傾向}

どの処理区においても二次林の先駆木本種である アオモジ, アカメガシワ，ムラサキシキブ，常緑高 木のクスノキ，ツブラジイなどが発芽し，木本 34 種 669個体，草本51種がみられた。表2によると，播き だし直後に発芽する種としてアカメガシワ，アオモ ジ,アオツジラフジ, 2年目に初めて発芽する種とし てクマノミズキが挙げられた。1，2年目ともに発芽 のみられた種としてアカメガシワ，ニガイチゴが挙 げられた。2年目から枯死の目立った種としてアオモ ジ，アオツジラフジが挙げられた。これらの

ことから，追加処理の違いが発芽種に与える影響は 少ないと考えられた。

\subsection{2. 木本発芽個体数の推移}

図5は施肥区における木本発芽個体数の推移を表 したものである。1年目は播きだし後 1 ～2 月で発芽

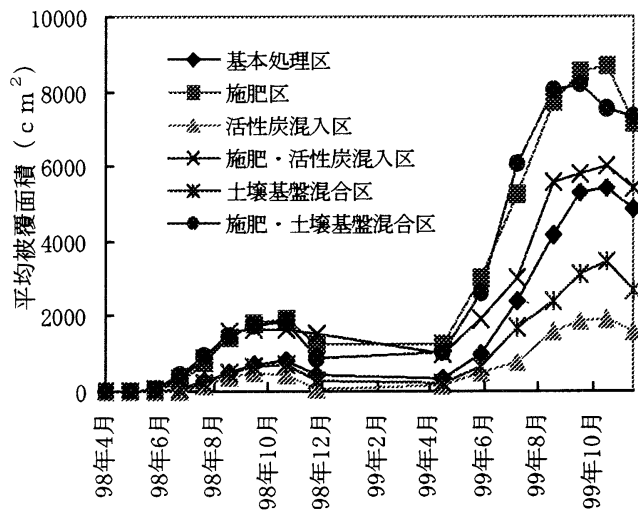

図6 アカメガシワの平均被覆面積の推移 数のピークを迎え, その後徐々に減少していった。2 年目は全体的に発芽が少なかった。どの処理区にお いても，このような傾向を示し，施肥区の方が無施 肥区よりも累積発芽数と生存個体数の差すなわち累 積枯死数が大きくなった。

\subsection{3. 初期成長}

図6は各処理区のアカメガシワの成長推移を表し たものである。全体的にみると，播きだし2ヶ月後か ら被覆面積值の高い施肥グループと被覆面積值の低 い無施肥グループに分けることができる。2年目も施 肥区のほうが無施肥区よりも増え方の大きい推移を 示した。これは， 1 年目の良好な成長が 2 年目にも利 いていると考えられた。施肥区のほうが無施肥区に 比べ樹高, 被覆面積ともに高い值を示し, 施肥の効 果が顕著にみられた。どの処理区においても 2 年目の 被覆面積が 1 年目に比べ数倍に増加し, 先駆性のア

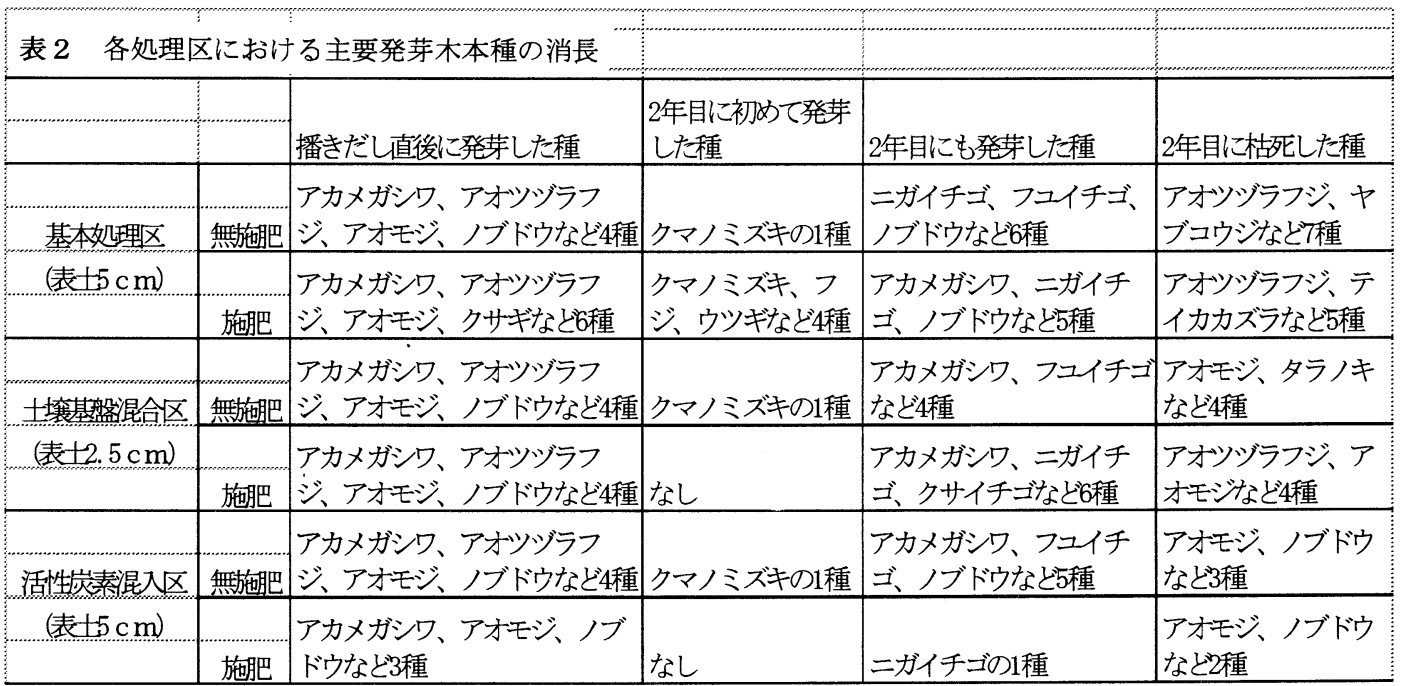




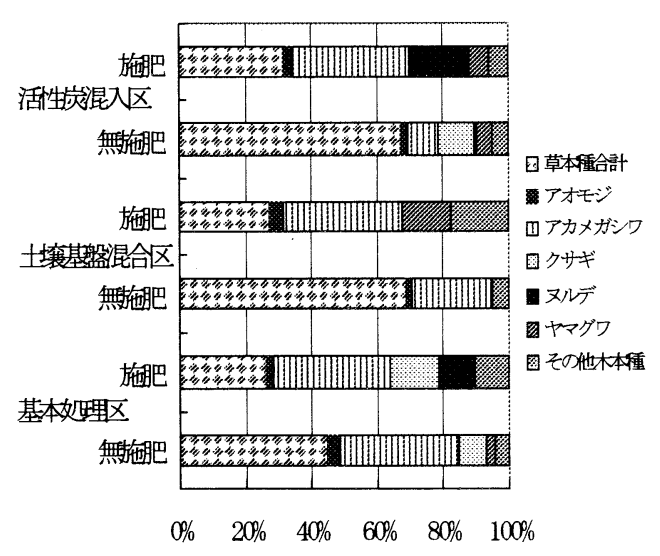

図 7 主要木本 5 種と草本種の優占関係

カメガシワが早期に優占したことを示す。

図7は9月に測定した乗算優占度を用いて，木本種 と草本種の優占関係を表した。どの処理区において も，施肥区のほうが，草本種の割合が低く，木本種 特にアカメガシワの割合が高くなった。これらのこ とから，施肥により木本種の成長が促進され，草本 種よりも早期に優占していると言える。 3.2.4まとめ
広い面積に播きだし粗放な管理下でも表土中に含 まれる埋土種子が発芽し，成長することが分かった。 また，施肥が先駆木本にとって，優占の一助となっ ており，早期の低木林成立を促進していると言える。

\section{4. 議論}

\section{1. 現地植生と播きだしによる発芽種}

表3は採取地の現地植生種と播きだしによって発 芽した種の比較を表したものである。現地植生種と 播きだしによって発芽した種との間の共通な種，「ア ベマキ林B」ではアラカシ，「シイ林」ではツブラジ イ，「アカマツ・モウソウチク林」ではヒサカキな ど, いくつかみられたが, どの森林タイプにおいて も類似度はかなり低い值を示した。また，現地には みられず播きだしによって発芽した種，「アベマキ 林B」ではクロモジ，「モウソウチク林」ではクスノ キ，「コナラーアオモジ林」ではウメモドキなどが みられた。これらのことから，モウンウチク林のよ うな現地植生が単純であっても，高い潜在性を持つ 森林表土が存在することは, 植生回復に対し, 森林 表土播きだし工法が現地植生だけからでは判断でき ない大きな可能性を持っていると言える。

表 3 現地植生と播きだし実験による発芽種の比較

\begin{tabular}{|c|c|c|c|c|}
\hline \multirow[b]{2}{*}{ 森林タイプ } & \multirow[b]{2}{*}{ 現地植生種 } & \multicolumn{2}{|c|}{ 実験での発芽種 } & \multirow{2}{*}{$\begin{array}{l}\text { ソレンセンン } \\
\text { の共通保数 }\end{array}$} \\
\hline & & 現地植生との共通種 & 現地植生にない種 & \\
\hline アベマキ林A & アベマキ、コナラなど54種 & アカメガシワ、ヤブコウジなど種 & ヤマハギ、マンリョウなど23種 & 0.19 \\
\hline アベマキ林B* & アベマキ、アラカシなど25種 & アラカシ、ソョゴなど4種 & ナワシログミ、クロモジなど33種 & 0.13 \\
\hline シイ林上部 & ツブラジイ、イチイガシなど20種 & ツブラジイ、イタビカズラなど種 & クスノキ、ヤマザクラなど24種 & 0.13 \\
\hline シイ林下部* & ツブラジイ、カゴノキなど15種 & ツブラジイ、ヤブムラサキの2種 & クマノミズキ、ナンテンなど36種 & 0.08 \\
\hline アカマツ林A & アカマツ、ウラジロガシなど28種 & ヒサカキ、ソヨゴの2種 & ハゼノキ、タラノキなど12種 & 0.10 \\
\hline アカマツ林B* & アカマツ、アカガシなど32種 & ヒサカキ、イソノキなとら種 & クロガネモチ、エノキなど23種 & 0.17 \\
\hline モウンウチク林* & モウソウチク、アベマキなど8種 & ヒサカキ、ネズミモチの2種 & クスノキ、ヤマザクラなど21種 & 0.13 \\
\hline コナラーアオモジ林 & コナラ、アオモジなど49種 & アオモジ、クマヤナギなど16種 & ウメモドキ、サネカズラなど69種 & 0.24 \\
\hline
\end{tabular}

\begin{tabular}{|c|c|c|c|c|c|c|c|}
\hline \multicolumn{4}{|c|}{ 表 4 各森林表土からの出現群落間の共通係数 } & \multirow[b]{2}{*}{ シ1 } & \multirow[b]{2}{*}{ モウソウ } & \multicolumn{2}{|c|}{ (*追加処理区も含む) } \\
\hline & アベマ & アベマ & シイ & & & アカマ & アカマ \\
\hline 森林タイプ & キ林 A & キ林 B * & 林上 & 林下* & チク林* & ツ林A & ツ林 B * \\
\hline \multicolumn{8}{|l|}{ アベマキ林A } \\
\hline アベマキ林 B * & 0.54 & & & & & & \\
\hline シイ林上 & 0.42 & 0.44 & & & & & \\
\hline シイ林下* & 0.57 & 0.54 & 0.72 & & & & \\
\hline モウソウチク林* & 0.65 & 0.60 & 0.55 & 0.48 & & & \\
\hline アカマツ林A & 0.27 & 0.35 & 0.39 & 0.35 & 0.59 & & \\
\hline アカマツ林 B * & 0.45 & 0.58 & 0.44 & 0.46 & 0.63 & 0.52 & \\
\hline \multirow[t]{2}{*}{ コナラーアオモジ林 } & 0.33 & 0.39 & 0.32 & 0.41 & 0.29 & 0.20 & 0.30 \\
\hline & & & & & \multicolumn{3}{|c|}{ 共通倸数 $\mathrm{C} C=2 \mathrm{Sc} /(\mathrm{S} 1+\mathrm{S} 2)$} \\
\hline
\end{tabular}


表4は各森林表土からの出現群落間の共通係数を 表したものである。各森林表土から成立した植物群 落間の類似度は，いずれも比較的高い值を示した。 これは，土壤を採取した森林内の構成種が異なって いても，その表土を播きだすことによって得られた 植物群落は類似したものになるということを示して いる。ただし，0.5を越えたからと言って，半分以上 が共通な種であるということを示しているわけでは ない。

\section{5. 結論}

森林表土播きだしは，低管理であっても，自然の 遷移に任せるよりも短い時間で低木林を成立させる ことができるため，造成工事などで出現する荒廃地 において, 植生回復や緑化を行う場合, 有効な工法 であると言える。また，施肥という補助的手段が発 芽後の木本種の生育に大きく寄与するという知見が 得られたことは，森林表土播きだしによる植生回復 工法をより確実なものにする 1 つの方向を示唆して いると言える。また，表土と基盤土壌やマサ土との 混合区において，発芽種数やその後の成長に他処理 区との違いがみられなかったことは，森林表土が多 少すくなくても基盤土壌と混合することにより，発 芽ポテンシャルをあまり低下させることなく，埋土 種子のポテンシャルを引き出すのが可能なことを示 している。これは，広大な土地を緑化する際，森林 表土量の節約につながる可能性を示唆している。

\section{6. 引用文献}

1）梅原徹・永野正弘・麻生順子（1983）：森林表土まき だしによる先駆植生の回復法 : 緑化工技術（3） 1-8

2）中越信和・鈴木兵二（1977）：宮島の森林群落におけ る埋土種子集団の研究 : ヒコビア8 (1-2)，180-192

3）越水麻子ほか（1997）：土壌シードバンクを用いた谷 戸植生復元に関する研究 : 保全生態学研究2，189-200

4）中越信和（1981）再度山の森林群落における埋土種子 集団の研究: 再度山永久植生保存地調查報告書第2回, 69-94（神戸市土木局公園緑地部）

5）永野正弘・梅原徹（1980）：森林表土のまきだしによ る植生回復法の検討 : 箕面川ダム自然回復の促進に関 する研究，6-113，大阪府

6）佐藤治雄ほか（1999）：森林表土播きだしによる荒廃 地緑化に関する基礎研究; ランドスケープ研究vol. 62, No. 5, 521-524

7）細木大輔・米村惣太郎・亀山章（1998）：埋土種子を 用いた法面緑化の研究 (3) : 日本緑化工学会研究発表 要旨集29, $112-115$

8）米村惣太郎・寺田直紀・亀山章（1997）：埋土種子を 用いた法面緑化の研究 : 日本緑化工学会研究発表要旨 集28, 255-258

9）米村䊍太郎・細木大輔・亀山章（1998）：埋土種子を 用いた法面緑化の研究 (2) : 日本緑化工学会研究発 表要旨集29，108-111

(2000. 4.8 受理)

Summary:This study`s object is to estimate forest seedbanks potential and to examine how it is used. Topsoil collected from Quercus variabilis forest and Phyllostachis pubescens forest in Ibaraki, Castanopsis cuspidata forest in Chihayaakasaka, Querucus serrata - Litsea sericea forest in Izumisano , Pinus densifrola forest in Nisinomiya applied on an experimental plot made of soil basis modeling disturbed area. Several experimental treatments such as mixing charcoal particles ,additional seeding Rhododendron reticulatum seed, fertilizing, mixing soil base were also applied.The live-and-die and growth every emerged plants were investigated . Pioneer spcies as Mollotus japonicus emerged on every plot, they keeped growing. Forest seedbanks is useful to revegetation of disturbed area , fertilizing treatment is more useful. 